\title{
OSOBOWOŚCIOWE UWARUNKOWANIA RYZYKA WYPADKÓW DROGOWYCH U KIEROWCÓW - PRZEGLĄD WYBRANYCH BADAŃ I PROPOZYCJA ICH INTERPRETACJI W RAMACH KOŁOWEGO MODELU METACECH OSOBOWOŚCI
}

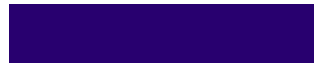 \\ HENRYK GASIUL * \\ WŁODZIMIERZ STRUS \\ Instytut Psychologii, Uniwersytet Kardynała Stefana Wyszyńskiego \\ Instytut Psychologii, Uniwersytet Kardynała Stefana Wyszyńskiego \\ w Warszawie
}

\section{STRESZCZENIE}

ściowymi uwarunkowaniami zachowań ryzykownych,
artykułu jest przeglad badań nad osobowopodatności na zmęczenie oraz wypadkowości w ruchu KOŁOWY MODEL METACECH OSOBOWOŚCI drogowym, a dalej próba ujęcia tych uwarunkowań w ramach Kołowego Modelu Metacech Osobowości (KMMO). Dotychczasowe badania oraz różnorodność stosowanych w nich modeli teoretycznych i narzędzi pomiaru sprawiają istotne trudności $\mathrm{w}$ integracji zgromadzonych danych empirycznych. Wydawało się, że Pięcioczynnikowy Model Osobowości, zwany też modelem Wielkiej Piątki, mógł spełniać taką funkcję syntetyzującą, jednak najnowsze badania i analizy wskazują na ograniczony potencjał integracyjny i teoretyczny tego modelu, szczególnie $\mathrm{w}$ porównaniu $\mathrm{z}$ modelami uwzględniającymi tzw. czynniki wyższego rzędu lub metacechy osobowości. Jednym $\mathrm{z}$ takich modeli jest właśnie KMMO, stąd też autorzy artykułu proponują uwzględnienie go jako modelu integrującego dotychczasowe zróżnicowane wyniki badań empirycznych nad osobowościowymi uwarunkowaniami zachowań ryzykownych, zmęczenia oraz wypadkowości w ruchu drogowym. Przedstawione w artykule analizy wykazały, że w tym kontekście istotne są 3 metacechy: Delta-minus/Poszukiwanie wrażeń, Alfa-minus/Rozhamowanie i Gamma-minus/Dysharmonia, a model predykcyjny oparty na tych szerokich zmiennych osobowościowych jest wartościowy w sensie oszczędności i trafności.

39 Cechy osobowości a wypadki drogowe i skłonność do zachowań ryzykownych na drodze

44 Cechy osobowości a podatność na zmęczenie jako czynniki ryzyka wypadków

48 KOłOWY MODEL METACECH OSOBOWOŚCI A SKŁONNOŚC DO ZACHOWAŃ RYZYKOWNYCH I PODATNOŚĆ NA ZMĘCZENIE U KIEROWCÓW

51 ZAKOŃCZENIE

52 BIBLIOGRAFIA 


\title{
PERSONALITY DETERMINANTS OF THE TRAFFIC ACCIDENT RISK OF DRIVERS - A REVIEW OF SELECTED STUDIES AND A PROPOSAL FOR THEIR INTERPRETATION WITHIN THE CIRCUMPLEX OF PERSONALITY METATRAITS MODEL
}

\begin{abstract}
The purpose of this article is a review of studies on the personality factors in risky behaviors, susceptibility to fatigue and the rate of accidents in motor vehicle traffic. We are also attempting to frame these factors within the Circumplex of Personality Metatraits (CPM) model. A large number of studies and a variety of models and measures used made the integration of the gathered empirical data difficult. While it initially appeared that the Five Factor Model of personality (also known as the Big Five model) could be used as the synthetizing function, most recent studies and analyses indicate that its potential in that respect is limited, especially when compared to models taking into account higher order factors (metatraits) of personality. One of such models is CPM and the authors propose its use as an integrating model for the existing variety of studies on the personality factors in risky behaviors, fatigue and traffic accidents. The analyses presented in the article have shown that 3 metatraits are important in this context: Delta-minus/Sensation Seeking, Alpha-minus/Disinhibition and Gamma-minus/Disharmony. We also show that a predictive model based on these broad personality variables is both parsimonious and relevant.
\end{abstract}

\section{KEYWORDS}

personality, accident rate, susceptibility to fatigue, risk behavior, higher-order factors,

Circumplex of Personality Metatraits 


\section{WPROWADZENIE}

R

yzyko wypadków drogowych wynika $z$ wielu czynników, spośród których zarówno sprawność pojazdu, warunki i stresory drogowe, organizacja pracy, jak i zmęczenie oraz ryzykowne zachowania samego kierowcy są szczególnie istotne. Niemniej warto postawić pytanie o znaczenie względnie trwałych indywidualnych dyspozycji kierowcy - przede wszystkim temperamentalnych i osobowościowych - jako czynników wyjaśniających z jednej strony podatność na zmęczenie, a z drugiej skłonność do zachowań ryzykownych i dzięki temu pozwalających na wyjaśnienie oraz przewidywanie ryzyka ulegania wypadkom lub ich powodowania. Wiele już przeprowadzono w tym zakresie analiz teoretycznych i badań empirycznych, wciąż jednak trudno o jednoznaczne wnioski; być może kluczowe znaczenie ma w tym względzie „dobroć” teorii czy modeli temperamentu i osobowości. Dotychczas obiecujące były przede wszystkim analizy znaczenia cech osobowości opisywanych przez tzw. Gigantyczną Trójkę H.J. Eysencka (PEN: psychotyzm, ekstrawersja, neurotyzm; Eysenck, Eysenck, 1985), Pięcioczynnikowy Model Osobowości (PMO; McCrae, Costa, 2005), zwany też modelem Wielkiej Piątki, model HEXACO (Ashton, Lee, 2007) czy psychobiologiczny model C. R. Cloningera (2004). Liczba badań oraz różnorodność stosowanych w nich modeli teoretycznych spowodowały jednak trudności z integracją zgromadzonych danych empirycznych i wytworzyły potrzebę uzyskania bardziej syntetycznego obrazu. Możliwość uzyskania takiego obrazu stwarza zaproponowany niedawno Kołowy Model Metacech Osobowości Strusa, Cieciucha i Rowińskiego (2014a). Prezentację tego modelu i jego potencjału integrującego, także w zakresie syntezy wyników badań nad uwarunkowaniami osobowościowymi ryzyka wypadków drogowych, poprzedzimy jednak prezentacją wybranych dotychczasowych rezultatów badań empirycznych.

\section{CECHY OSOBOWOŚCI A WYPADKI DROGOWE I SKŁONNOŚĆ DO ZACHOWAŃ RYZYKOWNYCH NA DRODZE}

Clarke i Robertson (2005) przeprowadzili szeroko zakrojoną metaanalizę wyników badań nad relacjami między cechami osobowości w ujęciu dominującego obecnie PMO (McCrae, Costa, 2005) a wypadkowością w pracy oraz w ruchu drogowym (osób będących kierowcami pojazdów). Model ten uwzględnia następujących pięć podstawowych cech osobowości: neurotyczność (N), ekstrawersję (E), otwartość na doświadczenia $(\mathrm{O})$, ugodowość (U) i sumienność (S). Trzeba jednak podkreślić, że wymienione wyżej cechy były mierzone różnymi kwestionariuszami, jak np. kwestionariuszem osobowości Eysencka (EPQi Eysenck, Eysenck, 1985), NEO-PI McCraea i Costy (2005), kwestionariuszem osobowości Cattella (16PF) czy też testem opartym na koncepcji poszukiwania doznań według Zuckermana. W tabeli 1 przedstawiono te wyniki metaanalizy Clarke i Robertsona (2005), które dotyczyły wyłącznie wypadków i kolizji drogowych, pominięto zaś dane odnoszące się do wypadków przy pracy. 
Tabela 1. Cechy osobowości a wypadki drogowe - dane empiryczne z metaanalizy Clarke i Robertsona (2005)

\begin{tabular}{|c|c|c|c|c|}
\hline $\begin{array}{l}\text { Autorzy badania } \\
\text { (data publikacji) }\end{array}$ & Próba & $\begin{array}{c}\text { Zmienna zależna } \\
\text { - wskaźnik wypadków }\end{array}$ & $\begin{array}{c}\text { Typ } \\
\text { danych }\end{array}$ & $\begin{array}{c}\text { Predyktory } \\
\text { - cechy osobowości }\end{array}$ \\
\hline Fine, B.J. (1963) & $\begin{array}{l}N=993 \text { studentów z USA; } \\
\text { mężczyźni w wieku } 19 \text { lat }\end{array}$ & Wypadki w ruchu drogowym & A & Ekstrawersja \\
\hline $\begin{array}{l}\text { Smith, D.I., Kirkham, R.W. } \\
\text { (1981) }\end{array}$ & $\begin{array}{l}N=113 \text { mężczyzn w wieku } \\
20-23 \text { lata z Australii }\end{array}$ & Liczba wypadków & A & $\begin{array}{l}\text { Ekstrawersja } \\
\text { Neurotyczność }\end{array}$ \\
\hline Suchman, E.A. (1970) & $\begin{array}{l}N=1562 \text { studentów oraz } \\
\text { uczniów szkół średnich } \\
\text { z USA }\end{array}$ & $\begin{array}{l}\text { Wypadki z osobami } \\
\text { rannymi w ciągu } \\
\text { minionego roku }\end{array}$ & $S$ & $\begin{array}{l}\text { Ekstrawersja } \\
\text { Sumienność (niska) }\end{array}$ \\
\hline $\begin{array}{l}\text { Pestonjee, D.M., Singh, U.B. } \\
\text { (1980) }\end{array}$ & $\begin{array}{l}N=40 \text { mężczyzn, kierow- } \\
\text { ców z Indii }\end{array}$ & $\begin{array}{l}\text { Liczba wypadków w okresie } \\
5 \text { lat }\end{array}$ & A & $\begin{array}{l}\text { Ekstrawersja } \\
\text { Neurotyczność }\end{array}$ \\
\hline $\begin{array}{l}\text { Shaffer, J.W., Towns, W., } \\
\text { Schmidt, C.W., Fisher, R.S., } \\
\text { Zlotowitz, H.I. (1974) }\end{array}$ & $N=50$ kierowców & $\begin{array}{l}\text { Uczestnictwo w wypadkach } \\
\text { z ofiarami śmiertelnymi }\end{array}$ & A & Ugodowość (niska) \\
\hline Shaw, L. (1965) & $\begin{array}{l}N=64 \text { kierowców autobu- } \\
\text { sów z Afryki Południowej }\end{array}$ & $\begin{array}{l}\text { Wskaźnik uczestnictwa } \\
\text { w wypadkach }\end{array}$ & A & $\begin{array}{l}\text { Neurotyczność } \\
\text { Ugodowość (niska) } \\
\text { Sumienność (niska) } \\
\text { Otwartość } \\
\text { Ekstrawersja }\end{array}$ \\
\hline $\begin{array}{l}\text { Tillman, W.A., Hobbs, G.E. } \\
\text { (1949) }\end{array}$ & $\begin{array}{l}N=40 \text { kierowców taksówek } \\
\text { z Kanady }\end{array}$ & $\begin{array}{l}\text { Wskaźnik wypadków } \\
\text { w kolejnych } 15 \text { latach }\end{array}$ & $S$ & $\begin{array}{l}\text { Otwartość } \\
\text { Sumienność (niska) } \\
\text { Neurotyczność }\end{array}$ \\
\hline Shaw, L., Sichel, H.S. (1971) & $\begin{array}{l}N=71 \text { białych kierow- } \\
\text { ców autobusów z Afryki } \\
\text { Południowej }\end{array}$ & $\begin{array}{l}\text { Liczba wypadków } \\
\text { (po udziale w badaniu) }\end{array}$ & A & $\begin{array}{l}\text { Sumienność (niska) } \\
\text { Neurotyczność } \\
\text { Ugodowość (niska) } \\
\text { Ekstrawersja }\end{array}$ \\
\hline $\begin{array}{l}\text { Andersson, A.L., Nilsson, A., } \\
\text { Henriksson, N. (1970) }\end{array}$ & $\begin{array}{l}N=44 \text { młodych kierowców } \\
\text { ze Szwecji; mężzzyźni } \\
\text { w wieku 20-27 lat }\end{array}$ & Wypadki w ruchu drogowym & A & Ekstrawersja \\
\hline $\begin{array}{l}\text { Selzer, M.L., Rogers, J.E., } \\
\text { Kern, S. (1968) }\end{array}$ & $N=192$ kierowców z USA & $\begin{array}{l}\text { Kierowcy } \\
\text { odpowiedzialni za } \\
\text { śmiertelne wypadki vs. } \\
\text { grupa kontrolna }\end{array}$ & A & Neurotyczność \\
\hline $\begin{array}{l}\text { Schumann, S.H., Pelz, D.C., } \\
\text { Ehrlich, N.J., Selzer, M.L. } \\
\text { (1967) }\end{array}$ & $\begin{array}{l}N=288 \text { młodych kierow- } \\
\text { ców; mężczyźni w wieku } \\
\text { 16-24 lata }\end{array}$ & $\begin{array}{l}\text { Liczba wypadków drogo- } \\
\text { wych w ciągu minionego } \\
\text { roku }\end{array}$ & $S$ & Sumienność (niska) \\
\hline Mayer, R.E., Treat, J.R. (1977) & $\begin{array}{l}N=60 \text { studentów z USA } \\
\text { w wieku 18-19 lat; } \\
36 \text { mężzzyzn i } 24 \text { kobiety }\end{array}$ & $\begin{array}{l}\text { Uczestnictwo w wypad- } \\
\text { kach drogowych vs. grupa } \\
\text { kontrolna }\end{array}$ & $S$ & $\begin{array}{l}\text { Sumienność (niska) } \\
\text { Neurotyczność }\end{array}$ \\
\hline $\begin{array}{l}\text { West, R.J., Elander, J., } \\
\text { French, D. (1993) }\end{array}$ & $\begin{array}{l}N=108 \text { kierowców z Wiel- } \\
\text { kiej Brytanii w wieku 38,1; } \\
59 \text { mężczyzn i } 49 \text { kobiet }\end{array}$ & $\begin{array}{l}\text { Liczba wypadków w kolej- } \\
\text { nych } 3 \text { latach }\end{array}$ & $S$ & Sumienność (niska) \\
\hline Vavrik, J. (1997) & $\begin{array}{l}N=100 \text { młodych kierow- } \\
\text { ców z Kanady; mężczyźni } \\
\text { w wieku 16-21 lat }\end{array}$ & $\begin{array}{l}\text { Winni wypadków w kolej- } \\
\text { nych } 2 \text { latach }\end{array}$ & A & $\begin{array}{l}\text { Sumienność (niska) } \\
\text { Ekstrawersja } \\
\text { Ugodowość (niska) } \\
\text { Otwartość }\end{array}$ \\
\hline $\begin{array}{l}\text { Smith, D.L., Heckert, T.M. } \\
\text { (1998) }\end{array}$ & $\begin{array}{l}N=76 \text { studentów z USA, } \\
\text { w wieku 18-21 lat; } \\
32 \text { mężczyzn i } 44 \text { kobiety }\end{array}$ & $\begin{array}{l}\text { Liczba wypadków } \\
\text { drogowych }\end{array}$ & $S$ & Ekstrawersja \\
\hline
\end{tabular}




\begin{tabular}{|c|c|c|c|c|}
\hline $\begin{array}{l}\text { Autorzy badania } \\
\text { (data publikacji) }\end{array}$ & Próba & $\begin{array}{c}\text { Zmienna zależna } \\
\text { - wskaźnik wypadków }\end{array}$ & $\begin{array}{c}\text { Typ } \\
\text { danych }\end{array}$ & $\begin{array}{c}\text { Predyktory } \\
\text { - cechy osobowości }\end{array}$ \\
\hline $\begin{array}{l}\text { Arthur, W., Graziano, W.G. } \\
\text { (1996) }\end{array}$ & $\begin{array}{l}N=227 \text { studentów } \\
\text { (college) oraz } \mathrm{N}=250 \\
\text { pracowników agencji pracy }\end{array}$ & $\begin{array}{l}\text { Liczba wypadków } \\
\text { drogowych }\end{array}$ & $S$ & $\begin{array}{l}\text { Ekstrawersja } \\
\text { Ugodowość (niska) } \\
\text { Sumienność (niska) } \\
\text { Neurotyczność } \\
\text { Otwartość }\end{array}$ \\
\hline $\begin{array}{l}\text { Trimpop, R., Kirkcaldy, B. } \\
\text { (1997) }\end{array}$ & $\begin{array}{l}\text { N=120 kierowców z Ka- } \\
\text { nady; mężczyźni w wieku } \\
\text { 16-29 lat }\end{array}$ & Liczba wypadków & $S$ & Ekstrawersja \\
\hline $\begin{array}{l}\text { Hemenway, D., Solnick, S.J. } \\
\text { (1993) }\end{array}$ & $\begin{array}{l}N=1799 \text { kierowców z USA; } \\
840 \text { mężczyzn i } 959 \text { kobiet }\end{array}$ & $\begin{array}{l}\text { Liczna wypadków w ciągu } \\
\text { minionego roku }\end{array}$ & $S$ & Ugodowość (niska) \\
\hline Furnham, A., Snaipe, J. (1993) & $\begin{array}{l}N=70 \text { kierowców w wieku } \\
19-61 \text { lat }\end{array}$ & Wypadki drogowe (stłuczki) & $S$ & $\begin{array}{l}\text { Ekstrawersja } \\
\text { Neurotyczność }\end{array}$ \\
\hline $\begin{array}{l}\text { Roy, G.S., Choudhary, R.K. } \\
\text { (1985) }\end{array}$ & $\begin{array}{l}N=75 \text { kierowców } \\
\text { autobusów z Indii; wszyscy } \\
\text { z 7-letnim stażem }\end{array}$ & Liczba wypadków & A & $\begin{array}{l}\text { Ugodowość (niska) } \\
\text { Neurotyczność } \\
\text { Ekstrawersja }\end{array}$ \\
\hline $\begin{array}{l}\text { Clement, R., Jonah, B.A. } \\
\text { (1984) }\end{array}$ & $\begin{array}{l}N=285 \text { studentów } \\
\text { z Kanady; } 130 \text { mężczyzn } \\
\text { i } 155 \text { kobiet }\end{array}$ & $\begin{array}{l}\text { Liczba wypadków } \\
\text { w kolejnych } 3 \text { latach }\end{array}$ & $S$ & Ekstrawersja \\
\hline Parker, J.W. (1953) & $\begin{array}{l}N=104 \text { mężczyzn, } \\
\text { zawodowych kierowców } \\
\text { ciężarówek }\end{array}$ & $\begin{array}{l}\text { Liczba wypadków } \\
\text { w przeliczeniu na } 5000 \text { mil }\end{array}$ & A & Otwartość \\
\hline Suhr, V.W. (1961) & $\begin{array}{l}N=60 \text { kierowców zawo- } \\
\text { dowych }\end{array}$ & Liczba wypadków & A & $\begin{array}{l}\text { Ekstrawersja } \\
\text { Otwartość } \\
\text { Sumienność (niska) }\end{array}$ \\
\hline Quenault, S.W. (1967) & $\begin{array}{l}N=100 \text { kierowców z Wiel- } \\
\text { kiej Brytanii }\end{array}$ & Wypadki w ruchu drogowym & $A$ & $\begin{array}{l}\text { Ekstrawersja } \\
\text { Neurotyczność }\end{array}$ \\
\hline $\begin{array}{l}\text { Panek, P.E., Wagner, E.E., } \\
\text { Barrett, G.V., Alexander, } \\
\text { R.A. (1978) }\end{array}$ & $\begin{array}{l}\text { N= } 175 \text { kierowców z USA; } \\
\text { kobiety w wieku 17-72 lata }\end{array}$ & $\begin{array}{l}\text { Liczba wypadków w ruchu } \\
\text { drogowym w kolejnych } \\
5 \text { latach }\end{array}$ & $S$ & Ugodowość (niska) \\
\hline $\begin{array}{l}\text { Lawton, R., Parker, D., } \\
\text { Manstead, A.S.R., Stradling, } \\
\text { S.G. (1997) }\end{array}$ & $\begin{array}{l}N=830 \text { kierowców z Wiel- } \\
\text { kiej Brytanii w wieku } \\
17 \text { lat; } 413 \text { mężczyzn } \\
\text { i } 417 \text { kobiet }\end{array}$ & $\begin{array}{l}\text { Liczba wypadków w ruchu } \\
\text { drogowym w kolejnych } \\
3 \text { latach }\end{array}$ & $S$ & Sumienność \\
\hline Burns, P.C., Wilde, G.J.S. (1995) & $\begin{array}{l}\text { N= } 51 \text { kierowców taksó- } \\
\text { wek; mężczyźni }\end{array}$ & Kolizje (zderzenia) & A & Ekstrawersja \\
\hline $\begin{array}{l}\text { Hartman, M.L., Rawson, H.E. } \\
\text { (1992) }\end{array}$ & $N=179$ studentów & Kolizje w ruchu drogowym & $S$ & Ekstrawersja \\
\hline $\begin{array}{l}\text { Lajunen, T., Summala, H. } \\
\text { (1996) }\end{array}$ & $\begin{array}{l}N=195 \text { żołnierzy z Finlan- } \\
\text { dii; mężczyźni }\end{array}$ & Kolizje (zderzenia) & $S$ & Ekstrawersja \\
\hline $\begin{array}{l}\text { Norris, E.H., Matthews, B.A., } \\
\text { Riad, J.K. (2000) }\end{array}$ & $\begin{array}{l}N=504 \text { osoby z USA w wie- } \\
\text { ku 19-88 lat; } 266 \text { mężczyzn } \\
\text { i } 238 \text { kobiet }\end{array}$ & $\begin{array}{l}\text { Wypadki w ruchu drogowym } \\
\text { w kolejnych } 4 \text { latach }\end{array}$ & $S$ & $\begin{array}{l}\text { Neurotyczność } \\
\text { Ugodowość (niska) }\end{array}$ \\
\hline
\end{tabular}

Adnotacja. A = dane archiwalne (udokumentowane źródła); $\mathrm{S}=$ dane samoopisowe.

Źródło: na podstawie Tabeli 1 w: Clarke, Robertson, 2005, s. 361-365.

Jak wynika $\mathrm{z}$ tej metaanalizy, szczególnie istotnymi predyktorami skłonności do wypadków - zarówno w pracy, jak i wypadków drogowych - są niska ugodowość i niska sumienność. Sumienność odgrywa istotną rolę w kontekście samokontroli, rozwagi, obowiązkowości, odpowiedzialności oraz przestrzegania zasad i norm społecznych, stąd niski poziom tej cechy może wiązać się z nieprzestrzeganiem kodeksu drogowego oraz impulsywnością. Wagę niskiej sumienności podkreślają także wyniki innych badań (np. Herzberg, 2009), nieuwzględnionych w metaanalizie Clarke i Robertsona (2005). Z kolei niska 
ugodowość związana jest $\mathrm{z}$ postawą egocentryczną, skłonnością do manipulacji oraz zachowaniami rywalizacyjnymi, co może skutkować agresywnym i nieliczącym się $\mathrm{z}$ innymi użytkownikami dróg stylem prowadzenia pojazdu. Ponadto umiarkowane znaczenie w kontekście ryzyka wypadków ujawniła także wysoka ekstrawersja. Co ciekawe - okazała się ona istotnym predyktorem wypadków drogowych, ale nie wypadków w pracy, co można próbować wyjaśnić tym, że sprawstwo wypadków drogowych może być skutkiem podatności na zmęczenie wynikające $\mathrm{z}$ monotonii i braku stymulacji. Ekstrawertycy mają wysokie zapotrzebowanie na stymulację, cenią aktywność i dlatego słabiej tolerują monotonię (np. związaną z prowadzeniem pojazdu na autostradzie) oraz mogą mieć podwyższoną skłonność do podejmowania zachowań ryzykownych (jako formy dostarczania sobie stymulacji). Jeśli natomiast chodzi o neurotyczność, to zgodnie z oczekiwaniami metaanaliza Clarke i Robertsona ujawniła jej dodatni związek z wypadkowością (powodowaniem wypadków), ale wniosek ten - odwrotnie niż w przypadku ekstrawersji - dotyczy wypadków w pracy, a nie wypadków drogowych. Co prawda podwyższona neurotyczność wiąże się z wrażliwością emocjonalną oraz niższą odpornością na stres (w tym stres drogowy) - co może skutkować wyższą podatnością na zmęczenie i skłonnością do rozpraszania uwagi w trakcie prowadzenia pojazdu - jednak obejmuje także tendencje do doświadczania strachu czy lęku, a emocje te moga powstrzymywać zachowania potencjalnie niebezpieczne na drodze. Rola neurotyczności w kontekście ryzyka powodowania wypadków w ruchu drogowym nie jest więc jednoznaczna, choć wiele badań wskazuje na istotny wpływ jej wysokiego poziomu (por. Clarke, Robertson, 2005). Poniekąd podobna sytuacja ma miejsce w przypadku otwartości na doświadczenia - metaanaliza Clarke i Robertsona (2005) wykazała, że istotnie sprzyja ona wypadkom w pracy, ale nie wypadkom na drodze - niemniej wyniki niektórych badań sugerują predykcyjne znaczenie otwartości także w przypadku tej drugiej kategorii wypadków. Otwartość na doświadczenia wiąże się bowiem z poznawczą preferencją nowości oraz wyobraźnią, a także niechęcią do konwencjonalnych i standardowych sytuacji bodźcowych (z czym z kolei związane jest zwykle prowadzenie pojazdu w normalnym ruchu drogowym). Należy jednak podkreślić, że otwartość na doświadczenia pojawiała się jako istotny predyktor wypadkowości w ruchu drogowym najrzadziej spośród wszystkich wymiarów PMO.

Podsumowując: konfiguracja pięciu podstawowych wymiarów osobowości, ujawniająca się w badaniach przytoczonych w tabeli 1 jako sprzyjająca wypadkom drogowym, obejmuje przede wszystkim: niską sumienność (S-), niską ugodowość (U-) i wysoką ekstrawersję $(\mathrm{E}+)$, a także (choć w mniejszym stopniu) podwyższoną neurotyczność $(\mathrm{N}+)$ oraz podwyższoną otwartość na doświadczenia $(\mathrm{O}+)$. Interpretując tę konfigurację łącznie, można zauważyć, że wiąże się ona z impulsywnością, egocentrycznością, rywalizacją oraz podatnością na rozpraszanie uwagi i ogólnie z podwyższoną skłonnością do zachowań ryzykownych.

Interesujące są także badania Herzberga (2009), który proponuje uwzględnienie typów osobowości rozumianych jako najczęściej występujące konfiguracje cech PMO w wyjaśnianiu zachowań na drodze. Dotychczasowe badania (por. Donnellan, Robins, 2010; Matthews, Campbell, 2009; Zawadzki, Strelau, 2003) wskazują na istnienie trzech prototypów osobowości: (1) typu odpornego (resilient; charakteryzującego się konfiguracją: $\mathrm{N}_{-}, \mathrm{E}+, \mathrm{O}+$, $\mathrm{U}_{+}, \mathrm{S}_{+}$, a więc niską neurotycznością oraz ponadprzeciętnym nasileniem pozostałych cech osobowości), (2) typu nadmiernie kontrolującego się (overcontrolled; charakteryzującego się konfiguracją: $\mathrm{N}_{+}, \mathrm{E}-, \mathrm{O}_{-}, \mathrm{S}_{+}$) oraz (3) typu niedostatecznie kontrolującego się (undercontrolled; z konfiguracją: $\left.\mathrm{N}+, \mathrm{O}_{+}, \mathrm{S}-, \mathrm{U}-\right)$. Typ odporny jest na ogół dobrze przystosowany i funkcjonuje poprawnie w większości sfer życia, w przeciwieństwie do pozostałych typów. Osoby nadmiernie się kontrolujące mają trudności w regulacji emocji i podwyższoną skłonność do zachowań o charakterze internalizacyjnym (np. niepokój, wycofanie społeczne), podczas gdy osoby kontrolujące się niedostatecznie mają tendencje do zachowań o charakterze eksternalizacyjnym (np. zachowania antyspołeczne, wykroczenia prawne). Herzberg 
(2009) przeprowadził badania na dwóch próbach - pierwsza obejmowała 172 kobiety i 177 mężczyzn, druga - 272 kobiety i 153 mężczyzn; wszyscy byli aktywnymi kierowcami niezawodowymi, przy czym w obu grupach dominowali studenci. Badani byli proszeni o podanie liczby wypadków oraz liczby wykroczeń (np. ukaranie mandatem, nadmierna prędkość, nieużywanie kierunkowskazów) w ostatnich trzech latach. Badanie przeprowadzono z użyciem kwestionariusza NEO-FFI do pomiaru PMO, a jego wyniki pozwoliły na potwierdzenie związków między prototypami osobowości a skłonnością do potencjalnie niebezpiecznych zachowań na drodze. Okazało się, że spośród trzech typów osobowości kierowców w wypadkach drogowych najczęściej uczestniczyli kierowcy niedostatecznie kontrolujący się, oni też najczęściej naruszali zasady ruchu i popełniali inne wykroczenia, szczególnie w stanie nietrzeźwości. Osoby o typie odpornym były najbardziej ostrożne i najmniej skłonne do prowadzenia pojazdu w stanie nietrzeźwości, choć ujawniały więcej zdarzeń drogowych niż osoby o typie nadmiernie się kontrolującym. Te ostatnie wykazały najmniejszą skłonność do wykroczeń i incydentów drogowych, co może być m.in. efektem wysokiej sumienności, którą w tym badaniu ujawnił typ nadmiernie kontrolujący się, a której (nieco paradoksalnie) zwykle nie ujawnia (por. Donnellan, Robins, 2010; Zawadzki, Strelau, 2003). Herzberg (2009, s. 1098) sądzi, że przyczyną otrzymanych wyników może być tzw. optymistyczne zniekształcenie percepcji ryzyka wypadku. Zjawisko to polega na tendencji do myślenia, że jest się mniej skłonnym do powodowania negatywnych zdarzeń na drodze - im silniejsze zniekształcenie optymistyczne, tym mniej zachowań zapobiegawczych, co zwrotnie prowadzi do podejmowania ryzyka i przekraczania prędkości na drodze, a to $z$ kolei są istotne predyktory możliwości powodowania wypadków. Ponadto niedocenianie spowodowania wypadku często wiąże się $\mathrm{z}$ przecenianiem własnych zdolności prowadzenia oraz iluzją kontroli. Dowody zebrane przez innych autorów wskazują, że optymistyczne zniekształcenie wiąże się z ekstrawersją oraz neurotycznością (za: Herzberg, 2009, s. 1099).

Obecnie najpoważniejszą alternatywą dla PMO, zyskującą coraz większą popularność wśród badaczy, staje się sześcioczynnikowy model HEXACO, uwzględniający takie wymiary osobowości jak: uczciwość-pokora, emocjonalność, ekstrawersja, ugodowość, sumienność i otwartość na doświadczenia (Ashton, Lee, 2007; zob. Skimina, Strus, Cieciuch, Szarota, Izdebski, 2020; Strus, Cieciuch, 2014). Obecność pierwszego z tych wymiarów stanowi najistotniejszą różnicę między modelami HEXACO i PMO.

Badania przeprowadzone ostatnio przez Burtaverdego, Chraif, Aniteia i Dumitru (2017) wskazują na istotne związki między cechami opisywanymi w ramach modelu HEXACO a zachowaniami ryzykownymi na drodze. Badania te przeprowadzono w dwóch grupach, z których jedną stanowili studenci psychologii $(N=227$ osób), a drugą osoby niebędące studentami $(N=244$ osoby). Grupa druga była badana online przez platformy społecznościowe. Wszyscy badani (obie grupy) wypełniali kwestionariusz HEXACO-PI (60-itemowy; zob. Skimina i in., 2020), kwestionariusz IPIP-BFM-50 (do pomiaru Wielkiej Piątki; Goldberg, 1999; zob. Strus, Cieciuch, Rowiński, 2014b) oraz dodatkowo: grupa pierwsza - Inwentarz ekspresji gniewu na drodze (DAX - Driving Anger Expression Inventory), a grupa druga - Wielowymiarowy inwentarz stylów prowadzenia (MDSI - Multidimensional Driving Style Inventory). Inwentarz DAX składa się z następujących podskal: werbalnej ekspresji agresji, fizycznej ekspresji agresji, ekspresji agresji wyrażanej sposobem prowadzenia pojazdu (np. próba zajechania komuś drogi) oraz ekspresji adaptacyjno-konstruktywnej (np. zwracanie komuś uwagi na bezpieczeństwo jazdy). Z kolei MDSI składa się z ośmiu podskal oceniających style prowadzenia: dysocjacyjny (np. błędna ocena prędkości mijanego pojazdu), nasycony niepokojem (np. poczucie nerwowości w trakcie prowadzenia), ryzykowny (np. podniecenie na skutek niebezpiecznego prowadzenia pojazdu), gniewny (np. przeklinanie innych kierowców), styl wysokiej prędkości (np. myślenie o sposobach jak najszybszego wydostania się z „korka”), styl redukcji dystresu (np. stosowanie technik relaksacji w trakcie prowadzenia pojazdu), styl cierpliwego prowadzenia (np. oparcie własnego 
zachowania na motcie „lepiej bezpiecznie niż z przykrymi następstwami”) czy styl uważny (ostrożny; Burtaverde, Chraif, Anitei, Dumitru, 2017, s. 5-6).

Wyniki uzyskane w obu grupach wskazują na szczególne znaczenie wymiaru uczciwość-pokora z modelu HEXACO dla bezpiecznych vs. niebezpiecznych reakcji i zachowań na drodze. W grupie 1 uzyskano ponadto istotne negatywne korelacje między składowymi agresji a ugodowością i sumiennością oraz między otwartością na doświadczenia a agresją fizyczną. Nie stwierdzono żadnych związków między ekstrawersją a agresywnością oraz między neurotycznością a agresywnością (poza jedną negatywną korelacją neurotyczności i agresji werbalnej). W grupie 2 natomiast, poza związkami ze wspomnianą uczciwością-pokorą, stwierdzono także negatywne związki między neurotycznością a ryzykownym stylem prowadzenia pojazdu oraz negatywne związki między ekstrawersją i otwartością na doświadczenia a stylem dysocjacyjnym oraz stylem nasyconym niepokojem. Szczególnie interesujące były jednak relacje między ugodowością oraz sumiennością a stylami prowadzenia pojazdu, a mianowicie: negatywne korelacje ze stylami dysocjacyjnym, nasyconym niepokojem, ryzykownym i gniewnym oraz pozytywne ze stylami cierpliwym i ostrożnym.

$Z$ powyższych badań wynikają dwa główne wnioski. Po pierwsze, konfiguracją cech osobowości sprzyjającą zachowaniom ryzykownym oraz wypadkom na drodze jest przede wszystkim konfiguracja obejmująca niską uczciwość-pokorę, a także niską sumienność i niską ugodowość. Po drugie, model HEXACO ujawnił przewagę nad PMO w kontekście predykcji zachowań niebezpiecznych i agresywnych na drodze, a HEXACO-PI okazał się w tym zakresie lepszym narzędziem prognostycznym niż IPIP-BFM-50.

\section{CECHY OSOBOWOŚCI A PODATNOŚĆ NA ZMĘCZENIE JAKO CZYNNIKI RYZYKA WYPADKÓW}

Analizując relacje między zachowaniami ryzykownymi i wypadkami na drodze a osobowością, nie sposób pominąć stanu zmęczenia, który także wydaje się możliwy do wyjaśnienia przez odniesienie do indywidualnych dyspozycji osobowościowych. Podatność na zmęczenie oraz sam stan zmęczenia w zasadniczej mierze warunkują ryzyko powodowania wypadków drogowych. Kilka wybranych badań przeprowadzonych w tym temacie dowodzi zasadności istnienia związków między tymi zmiennymi.

Na przykład Matthews (2011) poszukiwał relacji w obszarze różnic indywidualnych w podatności na zmęczenie. Bazując na skalach badających bipolarne pobudzenie, opracowanych przez Thayera (1996), Matthews (2011) zaproponował dymensjonalny model subiektywnych stanów doświadczanych w sytuacji wykonywania zadań obejmujących zarówno stany zmęczenia, jak i stresu. Pozycje składające się na opracowaną przez niego skalę DSSQ (Dundee Stress State Questionnaire) zawierają właśnie ocenę zmęczenia i stresu. Analizy pozwoliły na ujawnienie 10 powiązanych ze sobą komponentów, z których każdy odnosi się do jednej z tradycyjnie wyróżnianych stref: doświadczania, afektu, aktu woli (motywacji) oraz poznania. Komponenty te zawierały wymiary pobudzenia energetycznego (którego ujemnym biegunem jest zmęczenie) oraz pobudzenia napięciowego ( $\mathrm{z}$ biegunem ujemnym w postaci spokoju), zgodnie $z$ propozycją teoretyczną wspomnianego Thayera (1996). Dalsze analizy doprowadziły do wyróżnienia trzech wymiarów wyższego rzędu, tj. a) zaangażowania w zadanie, b) dystresu i c) zmartwienia. Wymiar zaangażowania w zadanie zawierał takie aspekty (i jednocześnie podskale DSSQ) jak: pobudzenie energetyczne, zainteresowanie zadaniem, motywacja sukcesu i koncentracja (niskie wyniki w zakresie tego wymiaru wskazują na stan zmęczenia, braku motywacji, zakłócenia uwagi); wymiar dystresu obejmował: napięcie, ton hedonistyczny (poziom doznawanej przyjemności-nieprzyjemności), zaufanie-kontrolę; wymiar zmartwienia natomiast - takie aspekty jak: skupienie na sobie, samoocenę oraz hamowanie poznawcze. 
Skale DSSQ mogą być dobrym instrumentem do pomiaru zmęczenia, zarówno sytuacyjnego, jak i indywidualnego, a zaangażowanie w zadania wyraźnie korelowało $\mathrm{z}$ objawami zmęczenia. Wśród tych ostatnich Saxby, Matthews i Hitchcock (Matthews, 2011, s. 211-212) na bazie przeglądu literatury podkreślają istotność czterech grup objawów zmęczenia: zmęczenia fizycznego (np. zmęczenie mięśni), zmęczenia - demotywacji (np. wyczerpanie, znudzenie), zmęczenia poznawczego i związanego z uwaga (np. trudności $\mathrm{z}$ wykonaniem pracy, dezorientacja, rozproszenie uwagi, marzenia) oraz radzenia sobie (np. stosowanie strategii pobudzania siebie). Do stanów najbardziej centralnych dla zmęczenia można natomiast zaliczyć utratę energii, motywacji oraz czujności (Matthews, 2011).

Niemniej kluczowe dla powyżej scharakteryzowanych wymiarów, aspektów i objawów stanu zmęczenia są różnice indywidualne w tym zakresie, a więc osobowościowa podatność na wystąpienie stanu zmęczenia oraz różnych elementów tego stanu. Uwzględniając różnice indywidualne, należy zawsze traktować analizy w kategoriach interakcyjnych między względnie stałymi cechami osobowości a jednostkową oceną sytuacji oraz zarządzaniem wymaganiami zadania i obciążeniami. Względnie stałe cechy osobowości mogą odpowiadać za poziom podatności na zmęczenie, niektórzy badacze traktują zaś podatność na zmęczenie wprost jako cechę osobowości. $Z$ badań przeprowadzonych wśród kierowców przez Matthewsa i Campbell (2009) wynika, że istotną cechą wyjaśniającą podatność na zmęczenie jest sumienność, która stanowi prawdopodobnie swego rodzaju podłoże zaangażowania w aktywność pracy. Dość niejasne jest natomiast znaczenie ekstrawersji. $Z$ jednej strony można byłoby oczekiwać, że niejednokrotnie bardzo monotonna sytuacja prowadzenia pojazdu będzie powodować większe zmęczenie u ekstrawertyków, którzy (zgodnie z duchem interpretacji Eysencka) cechują się większym zapotrzebowaniem na stymulację. $Z$ drugiej strony jednak deprywacja sensoryczna, sama w sobie działająca jako stresor, może być bardziej obciążająca dla introwertyków, tym bardziej że to ekstrawertycy są w większym stopniu skłonni do doświadczania i poszukiwania pozytywnych, pobudzających emocji, które moga przeciwdziałać zmęczeniu (zgodnie z teorią wrażliwości na wzmocnienia; Corr, 2009). Cytowane badania Matthewsa (2011) - w których analizie poddano związki aspektów stanu zmęczenia mierzonych przez skale DSSQ ze skalami mierzącymi cechy osobowości według PMO - wykazały, że zaangażowanie przed realizacją zadania (tzw. zaangażowanie przedzadaniowe), oceniane na podstawie siły pobudzenia energetycznego, zainteresowania zadaniem, motywacji sukcesu i koncentracji, korelowało dość wysoko dodatnio z sumiennością, ugodowością i ekstrawersją oraz ujemnie $z$ neurotycznością. $Z$ kolei zaangażowanie po realizacji zadania (tzw. postzadaniowe zaangażowanie w wykonanie) korelowało wyłącznie ujemnie z neurotycznością. Niestety wyniki te trudno uznać za reprezentatywne dla relacji między cechami osobowości a podatnością na zmęczenie.

Wydaje się jednak, że cenne światło na osobowościowo-temperamentalne uwarunkowania zmęczenia może rzucić analiza wyników badań prowadzonych także na grupach innych niż kierowcy. Na przykład Gonzalez i in. (2014) przeprowadzili badania wśród pielęgniarek pracujących w madryckich szpitalach, dokonując pomiaru PMO, pozytywnego i negatywnego afektu na poziomie stanu oraz doświadczenia zmęczenia pod koniec pracy. Skala zmęczenia (subiektywna ocena, na skali 10-punktowej, poszczególnych symptomów zmęczenia będącego konsekwencją wykonywanej pracy) mierzyła w sumie jego pięć wymiarów: brak energii, wysiłek fizyczny, dyskomfort fizyczny, brak motywacji oraz senność. Pomijając bardziej szczegółowe analizy - okazało się, że pielęgniarki o niższym poziomie ekstrawersji (bardziej introwertywne) w warunkach wysokiego zmęczenia doświadczały pozytywnego afektu w sposób mniej nasilony niż pielęgniarki o wyższym poziomie ekstrawersji; w warunkach niskiego zmęczenia natomiast nie ujawniły się istotne różnice w zakresie pozytywnego afektu między osobami o różnym poziomie ekstrawersji.

$Z$ kolei neurotyczność różnicowała poziom negatywnego afektu w obu grupach - pielęgniarki o wysokiej neurotyczności doświadczały wyższego poziomu negatywnego afektu 
niż pielęgniarki o niskiej neurotyczności (stabilne emocjonalnie) zarówno w warunkach niskiego, jak i wysokiego zmęczenia - chociaż większe znaczenie dla afektu negatywnego cecha ta ujawniła w warunkach wysokiego zmęczenia. Zmęczenie okazało się zatem istotnym moderatorem relacji między ekstrawersją i pozytywnym afektem oraz między neurotycznością a afektem negatywnym. Wyniki te można zinterpretować także jako wskazujące na fakt, że najbardziej podatne na zmęczenie są osoby introwertywne (E-) i zarazem neurotyczne $(\mathrm{N}+)$, ponieważ to u tych osób najmocniej oddziaływało na pogorszenie aktualnego nastroju (spadek pozytywnego i wzrost negatywnego afektu). Ponadto pozytywny afekt, do którego doświadczania bardziej skłonne są osoby ekstrawertywne, może działać zwrotnie w charakterze bufora chroniącego przed objawami zmęczenia, neurotyczność natomiast wiąże się z podwyższoną pobudliwością na obciążenia fizyczne, somatyczne i psychiczne oraz wrażliwością na sygnały kary, co samo w sobie usposabia do intensyfikacji negatywnego afektu i zwrotnie do pogłębiania się stanu zmęczenia. Innymi słowy, osoby neurotyczne w większym stopniu skupiają uwagę na oznakach zmęczenia i postrzegają je jako bardziej nasilone, co może prowadzić do wzrostu negatywnego afektu, a dalej - także do wzrostu subiektywnego odczucia zmęczenia.

Wiele innych badań nad znaczeniem neurotyczności (por. np. Gunthert, Cohen, Armelli, 1999; Kangas, Montgomery, 2011) wskazuje na skłonność osób o podwyższonym nasileniu tej cechy do częstszego (lub bardziej intensywnego) przeżywania negatywnych doświadczeń życiowych i stresu, a w warunkach zmęczenia - do doświadczenia w sposób bardziej intensywny zmęczenia objawiającego się spadkiem energii i wysokim poziomem napięcia oznaczającego obniżony nastrój. Dla przykładu: znacznie wcześniej przeprowadzone badania Gunthert i in. (1999) dowiodły, że osoby neurotyczne z reguły wyolbrzymiają zagrożenia, nie doceniają natomiast własnych zasobów umożliwiających radzenie sobie z problemami. W sytuacji zmęczenia (braku energii) pojawia się u nich także tendencja do utraty zaufania własnym zdolnościom do poradzenia sobie z problemami czy własnymi stanami emocjonalnymi i do zamykania się na możliwe stany przyjemności. Osoby neurotyczne mają ponadto tendencje do myślenia katastroficznego (por. np. Kangas, Montgomery, 2011). Silny związek między neurotycznością a podatnością na zmęczenie można uznać za potwierdzony w szerokim zakresie badań empirycznych.

Jeśli chodzi o badania nad relacją osobowość-podatność na zmęczenie, prowadzone w kontekście innego modelu cech niż PMO i w grupie osób o skrajnym nasileniu owej podatności, to warto zwrócić uwagę na badania Fukudy i in. (2010). Objęły one osoby cechujące się syndromem chronicznego zmęczenia (211 pacjentów) oraz grupę kontrolną 90 osób, które wypełniły kwestionariusz TCI (Temperament and Character Inventory) Cloningera (2004), oparty na jego psychobiologicznym modelu cech temperamentu i charakteru, oraz 14-itemową skalę CFS (Chalder Fatigue Scale), mierzącą zmęczenie umysłowe oraz fizyczne. Badania te przyniosły kilka interesujących wyników w zakresie różnic między badanymi grupami i związków między uwzględnionymi zmiennymi. Po pierwsze, podgrupa pacjentów leczonych psychiatrycznie ujawniła wyższy poziom zmęczenia niż pacjenci niepsychiatryczni. Po drugie, pacjenci z chronicznym zmęczeniem i zaburzeniami psychiatrycznymi ujawnili niższy poziom kierowania sobą (self-directedness) jako cechy charakteru w porównaniu z pacjentami z chronicznym zmęczeniem, ale bez chorób psychicznych. Po trzecie, wyniki wskazywały na dodatni związek między poziomem zmęczenia a cechą temperamentu unikanie szkody (harm avoidance) oraz na ujemne związki zmęczenia $\mathrm{z}$ takimi cechami charakteru jak kierowanie sobą oraz skłonność do współpracy (cooperativeness), także wśród pacjentów $\mathrm{z}$ chronicznym zmęczeniem. Biorąc pod uwagę relacje między modelem Cloningera a PMO, można wnioskować o kolejnym dowodzie na sprzyjające zmęczeniu znaczenie neurotyczności (odpowiednik unikania szkody), a ponadto na znaczenie takich cech jak: niska sumienność (obok ugodowości związana $z$ kierowaniem sobą) oraz niska ugodowość (związana ze skłonnością do współpracy). Badania te potwierdziły 
bowiem, że konfiguracja neurotyczności (unikania szkody) oraz niskiego poziomu samoregulacji oraz umiejętności społecznych i komunikacyjnych sprzyja tendencji do pojawienia się symptomów chronicznego zmęczenia.

Model oraz kwestionariusz TCI Cloningera zastosowano również w badaniu Yamano $\mathrm{i}$ in. (2010). W badaniu tym pomiaru zmęczenia dokonano jednak za pomocą skali CCFS (Childhood Chronic Fatigue Syndrome), a jego uczestnikami byli adolescenci. Uzyskane wyniki wskazują, że podatności na zmęczenie objawiającej się symptomami fizycznymi i umysłowymi sprzyjają takie cechy temperamentu jak: poszukiwanie nowości (novelty seeking) i unikanie szkody, a także cecha charakteru kierowanie sobą. Wyniki te pośrednio wskazują znowu na znaczenie wymiarów neurotyczności, niskiej sumienności oraz ekstrawersji.

Podsumowując, powyżej przytoczone wybrane wyniki badań i analiz pozwalają wnioskować, że cechą osobowości najbardziej sprzyjającą zmęczeniu (w tym zapewne także zmęczeniu kierujących pojazdami w ruchu drogowym) jest neurotyczność. Osoby neurotyczne są bardziej podatne na stres, bardziej pobudliwe i wrażliwe na sytuacje wywołujące negatywne emocje, dlatego silniej reagują na negatywne sytuacje ( $\mathrm{w}$ tym zapewne także na negatywne sytuacje drogowe), a w odpowiedzi na nie częściej przeżywają negatywne stany uczuciowe. Ponadto osoby te szybciej się męczą, intensywniej odczuwają objawy zmęczenia i potrzebują więcej czasu na odzyskanie sił do pracy, a także częściej doświadczają wahań samooceny, której aspektem jest również poczucie własnej kompetencji jako kierowcy.

Ten ostatni aspekt wiąże się jeszcze z drugim istotnym osobowościowym predyktorem zmęczenia - sumiennością, której niski poziom łącznie $\mathrm{z}$ neurotycznością stanowi konfigurację cech szczególnie sprzyjających podatności na zmęczenie. Znaczenie ekstrawersji jest bardziej skomplikowane, $z$ jednej strony bowiem niskie nasilenie tej cechy (introwersja) zwiększa podatność na stres i zmęczenie, a $z$ drugiej strony także wysoki poziom ekstrawersji nie jest korzystny, jeśli towarzyszy jej wysoka neurotyczność (szczególnie przy niskiej sumienności). Taka „choleryczna” konfiguracja cech (por. Eysenck, Eysenck, 1985) predysponuje bowiem do impulsywnych zachowań $i$ intensywnego poszukiwania stymulacji, a w świetle wcześniej cytowanych badań relacja neurotyczność-negatywny afekt może stanowić swego rodzaju zaplecze hamujące relację między ekstrawersją a pozytywnym afektem. Zatem znaczenie ekstrawersji w kontekście podatności na zmęczenie jest możliwe do wyjaśnienia jedynie $w$ układzie interakcji $z$ innymi wymiarami osobowości oraz przy uwzględnieniu dostępności czynników umożliwiających utrzymanie lub pobudzenie pozytywnych stanów emocjonalnych.

Przedstawione wyżej wyniki badań nad osobowościowymi uwarunkowaniami zarówno wypadków drogowych i skłonności do zachowań ryzykownych na drodze, jak i podatności na zmęczenie z jednej strony prowadzą do stosunkowo zbieżnych wniosków, z drugiej zaś nie są do końca sprowadzalne do siebie. W badaniach tych wykorzystywano bowiem różne modele teoretyczne i różne narzędzia ich pomiaru, a wnikliwa analiza wyników doprowadza do konkluzji, że - oprócz sygnalizowanych zbieżności - w znacznym zakresie różnią się one od siebie tym, jakie istotne predyktory osobowościowe ujawniały, jak również ich liczbą.

Pokaźna liczba badań oraz różnorodność zastosowanych w nich modeli i narzędzi stwarza więc trudności $z$ integracją zgromadzonych danych empirycznych, a zarazem potrzebę uzyskania bardziej syntetycznego obrazu. Pomimo tego, że PMO do pewnego stopnia umożliwia wzajemną przekładalność tych wyników (por. McCrae, Costa, 2005; McCrae, John, 1992), nowe badania i analizy wskazują na ograniczony potencjał integracyjny i teoretyczny tego modelu, szczególnie w porównaniu z najnowszymi modelami skonstruowanymi w badaniach nad strukturą osobowości i uwzględniającymi tzw. czynniki wyższego rzędu lub metacechy osobowości. Jednym z takich modeli jest Kołowy Model Metacech 
Osobowości (KMMO) Strusa i in. (2014a; Strus, Cieciuch, 2017; zob. np. Rogoza, Cieciuch, Strus, Baran, 2019).

\section{KOKOWY MODEL METACECH OSOBOWOŚCI A SKŁONNOŚĆ DO ZACHOWAŃ RYZYKOWNYCH I PODATNOŚĆ NA ZMĘCZENIE U KIEROWCÓW}

PMO jest dominującą w psychologii taksonomią cech osobowości. Kluczowe założenia tego modelu dają się sprowadzić do tezy, że wszystkie cechy osobowości człowieka są zorganizowane w ramach pięciu ogólnych i niezależnych od siebie wymiarów. Owa Wielka Piątka ma więc konstytuować najwyższy poziom hierarchicznie zorganizowanej struktury osobowości. Jednakże nasilona i poparta wieloma badaniami krytyka formułowana przez licznych badaczy (por. np. Block, 1995, 2001; McAdams, 1992) doprowadziła do zakwestionowania kilku kluczowych założeń tego modelu (zob. Gasiul, 2020; Strus, Cieciuch, 2014). Główne zarzuty wobec PMO dotyczyły jego a) ateoretycznego, wyłącznie opisowego charakteru, b) liczby podstawowych wymiarów oraz c) ich ortogonalności (Strus i in., 2014a). W 1997 roku Digman (1997) opublikował analizy dowodzące, że systematyczne interkorelacje pięciu wymiarów PMO wskazują na istnienie dwóch cech wyższego rzędu (metacech), znajdujących się w strukturze osobowości ponad Wielką Piątką. Wspólna wariancja stabilności emocjonalnej (odwrotny biegun neurotyczności), ugodowości i sumienności konstytuuje Alfę (czynnik socjalizacji), ekstrawersja i otwartość tworzą natomiast Betę (czynniki osobistego rozwoju). Prowadzone przez następne 20 lat intensywne badania potwierdzily istnienie tych dwóch metacech, a nawet doprowadziły do odkrycia tzw. ogólnego czynnika osobowości (GFP; General Factor of Personality; Musek, 2007; Rushton, Irving, 2011), znajdującego się na samym szczycie jej struktury, powyżej Alfy i Bety. O ile idea GFP wzbudziła wiele kontrowersji (por. Just, 2011; Revelle, Wilt, 2013; Zawadzki, Strelau, 2014), o tyle metacechy Alfa i Beta uzyskały silne wsparcie empiryczne i obecnie traktowane są zwykle jako ortogonalne wymiary ulokowane na najwyższym poziomie struktury cech osobowości i najczęściej nazywane są odpowiednio: Stabilnością i Plastycznością (DeYoung, 2006; Digman, 1997; Strus, Cieciuch, 2017).

KMMO (Strus, Cieciuch, 2017; Strus i in., 2014a) nawiązuje bezpośrednio do zreferowanych powyżej badań i stanowi propozycję, aby odkryte przez Digmana (1997) oraz zrekonceptualizowane przez DeYounga, Petersona i Higginsa (2002) metacechy Alfę/Stabilność oraz Betę/Plastyczność potraktować jako ortogonalne wymiary przestrzeni kołowej. W związku z tym KMMO postuluje istnienie dwóch kolejnych metacech: Gammy/ Integracji (odpowiednik GFP) oraz Delty/Powściągliwości. Gamma i Delta są ortogonalne względem siebie oraz zrotowane o 45 stopni względem Alfy i Bety. Ponadto każda z metacech ma dwa bieguny zdefiniowane nie tylko w kategoriach przeciwieństw, ale też odrębnych jakości i wyrażające się w określonej konfiguracji czynników PMO (zob. rysunek 1). Zatem drugim biegunem Alfy-plus/Stabilności jest Alfa-minus/Rozhamowanie, drugim biegunem Bety-plus/Plastyczności jest Beta-minus/Pasywność. Biegunami Gammy są Integracja (Gamma-plus) oraz Dysharmonia (Gamma-minus), biegunami Delty zaś - Powściągliwość (Delta-plus) oraz Poszukiwanie wrażeń (Delta-minus). 


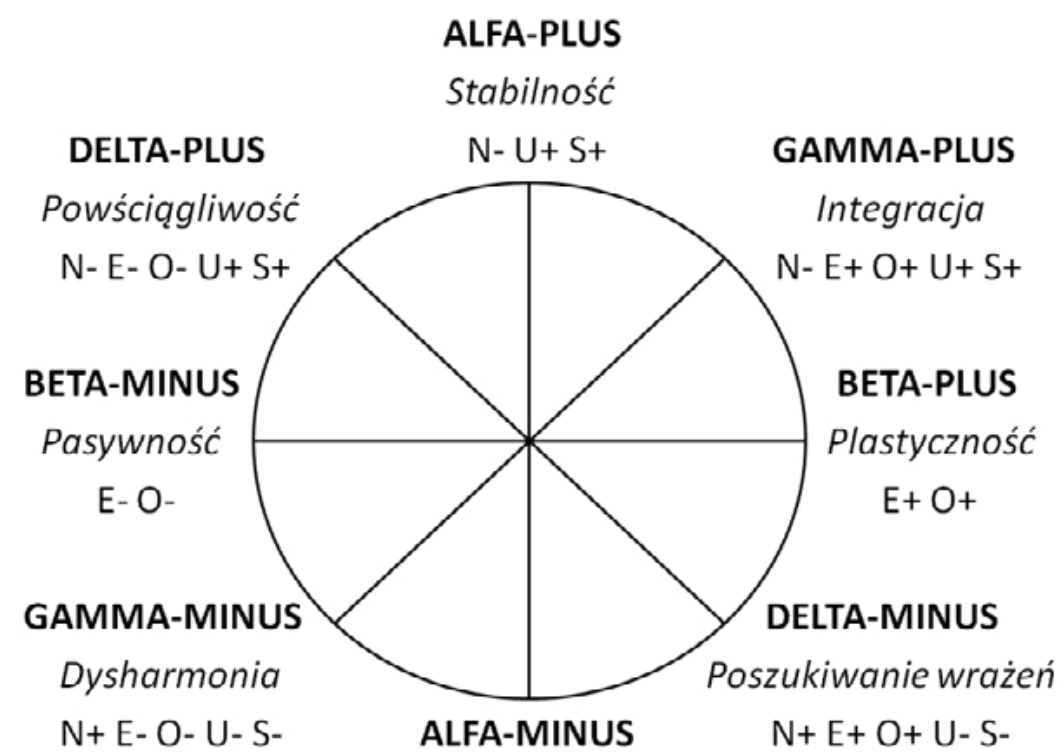

Rozhamowanie

$\mathrm{N}+\mathrm{U}-\mathrm{S}-$

$\mathrm{N}$ - neurotyczność

E - ekstrawersja

O - otwartość na doświadczenia

U - ugodowość

S - sumienność

+ - dodatni biegun cechy

- - ujemny biegun cechy

Rysunek 1. Kołowy Model Metacech Osobowości.

Metacechy ujmują osobowość w najbardziej ogólnych kategoriach, stanowiąc nie tyle proste kombinacje cech PMO, co nową jakość wynikającą z ich interakcji (Strus, Cieciuch, 2017). Szczególnie ważną właściwością KMMO jest jego potencjał integracyjny - pozwala on na integrację innych modeli teoretycznych opisujących osobowość, temperament, zachowania interpersonalne, emocje, motywację, zdrowie psychiczne i psychopatologię czy typy osobowości, co zostało już w dużej mierze potwierdzone empirycznie (Strus, Cieciuch, 2017; Strus, Cybis, Cieciuch, Rowiński, 2021; Zawadzki, 2017). W kontekście wyżej przytoczonych badań nad osobowościowymi uwarunkowaniami zachowań ryzykownych oraz podatności na zmęczenie w ruchu drogowym istotne jest to, że w KMMO można ulokować także konstrukty z modeli PEN, HEXACO (Strus, Cieciuch, 2021) czy psychobiologicznego modelu Cloningera. Przykładowo uczciwość-pokora (HEXACO) wykazuje treściowe związki z Alfą/Stabilnością, kierowanie sobą oraz skłonność do współpracy (model Cloningera) - z Alfą/Stabilnością oraz Gammą/Integracją, unikanie szkody - z Gammą-minus/Dysharmonią i Betą-minus/Pasywnością, a poszukiwanie nowości - z Deltą-minus/ Poszukiwaniem wrażeń. Związki KMMO z PMO są oczywiste, ale warto zwrócić uwagę, że trzy prototypy osobowości odkryte w badaniach nad PMO (por. Donnellan, Robins, 2010; Zawadzki, Strelau; 2003) odpowiadają konfiguracjom tworzącym metacechy Gamma-plus/Integracja (typ odporny), Gamma-minus/Dysharmonia (typ nadmiernie kontrolujący się; choć akurat w wyżej cytowanym badaniu Herzberga [2009] typ ten korespondował bardziej z Deltą-plus/Powściągliwością) oraz Delta-minus/Poszukiwanie wrażeń (typ 
niedostatecznie kontrolujący się; por. Strus i in., 2014a; Strus i in., 2021; Zawadzki, 2017). Te relacje oraz omówione wyżej badania pozwalają ulokować osobowościowe predyktory zmęczenia, ryzykownych zachowań oraz wypadków na drodze w obszarze między Deltą-minus/Poszukiwaniem wrażeń a Gammą-minus/Dysharmonią, integrując te, nierzadko rozproszone, wyniki badań i prezentując syntetyczny obraz osobowościowych uwarunkowań skłonności do wypadków na drodze (zob. rysunek 2).

Z badań Hirsha, DeYounga i Petersona (2009) wynika, że Beta/Plastyczność związana jest $\mathrm{z}$ zaangażowaniem $\mathrm{w}$ szeroki zakres adaptacyjnych aktywności behawioralnych (np. w zachowania społeczne, realizację własnych zainteresowań), Alfa/Stabilność natomiast $-\mathrm{z}$ powstrzymywaniem się od szerokiego zakresu zachowań dysfunkcjonalnych (np. zachowań antyspołecznych, zażywania substancji psychoaktywnych). Zatem Delta-minus (czyli kombinacja wysokiej plastyczności i niskiej stabilności) wiąże się z nasiloną, ale słabo kontrolowaną aktywnością, co potwierdzają badania wskazujące na jej związki z impulsywnością, skłonnością do ryzyka i tendencjami do problemów eksternalizacyjnych (DeYoung, Peterson, Seguin, Tremblay, 2008; Strus, Cieciuch, 2017) oraz z wysoką aktywnością behawioralnego systemu aktywacji (BAS; Strus, Cieciuch, 2017). W KMMO Delta-minus zawiera kombinację neurotyczności, niskiej sumienności, niskiej ugodowości oraz wysokiej ekstrawersji i otwartości na doświadczenia (N+, E+, O+, U-, S-) i wiąże się $\mathrm{z}$ wysoką labilnością emocjonalną, poszukiwaniem stymulacji, tendencją do dominowania i ekspansywnością w relacjach międzyludzkich (por. DeYoung i in., 2008). Z kolei Gamma-minus (czyli kombinacja niskiej stabilności i niskiej plastyczności) wiąże się z niską aktywnością oraz ze słabością samoregulacji własnych zachowań i emocji (por. Becker, 1999), co pozostaje $\mathrm{w}$ związku $\mathrm{z}$ depresyjnością i tendencjami do problemów internalizujących powstających na podłożu wysokiej reaktywności emocjonalnej i wrażliwości behawioralnego systemu hamowania (BIS; Strus, Cieciuch, 2017). KMMO opisuje Gammę-minus jako związaną $\mathrm{z}$ niedostępnością $\mathrm{w}$ relacjach interpersonalnych oraz $\mathrm{z}$ pesymizmem i ogólnie niskim poziomem dobrostanu psychicznego i fizycznego oraz ze skłonnością do problemów psychicznych (por. Becker, 1999; Musek, 2007; Rushton, Irving, 2011; Strus Cieciuch, 2017), jako że obejmuje ona najbardziej dysfunkcjonalną (szczególnie w perspektywie intrapsychicznej) konfigurację cech osobowości: neurotyczność oraz niskie nasilenie sumienności, ugodowości, ekstrawersji i otwartości na doświadczenia.

$\mathrm{Na}$ rysunku 2 przedstawiono schemat hipotetycznych powiązań między metacechami Delty-minus oraz Gammy-minus a podatnością na zmęczenie, tendencjami do zachowań ryzykownych oraz wypadkowością na drodze. Zgodnie z tym schematem Delta-minus jest osobowościową determinantą zachowań ryzykownych, szczególnie w sytuacji długotrwałego i monotonnego prowadzenia pojazdu i związanego $\mathrm{z}$ nim narastającego zmęczenia. Gamma-minus wiąże się z podatnością na zmęczenie i związane z nim nasilenie takich jego objawów jak wyczerpanie czy spadek koncentracji uwagi, szczególnie w warunkach długotrwałego obciążenia prowadzeniem pojazdu. Warto zwrócić uwagę na dodatkową predykcję związaną z metacechą znajdującą się w KMMO między Gammą-minus oraz Deltą-minus. Tą metacechą jest Alfa-minus/Rozhamowanie, zawierająca konfigurację wysokiej neurotyczności, niskiej sumienności i niskiej ugodowości. Wiąże się ona z wysokim poziomem tendencji antyspołecznych powstających na podłożu niezrównoważenia i niskiej tolerancji na frustrację, a ujawniających się w agresywności i antagonizmie w stosunku do ludzi, norm i zobowiązań społecznych (por. Becker, 1999; Settles i in., 2012). Wysokie nasilenie tej metacechy osobowości będzie się wyrażać w zachowaniach agresywnych na drodze, szczególnie w warunkach długotrwałego prowadzenia pojazdu i związanego z nim zmęczenia. 


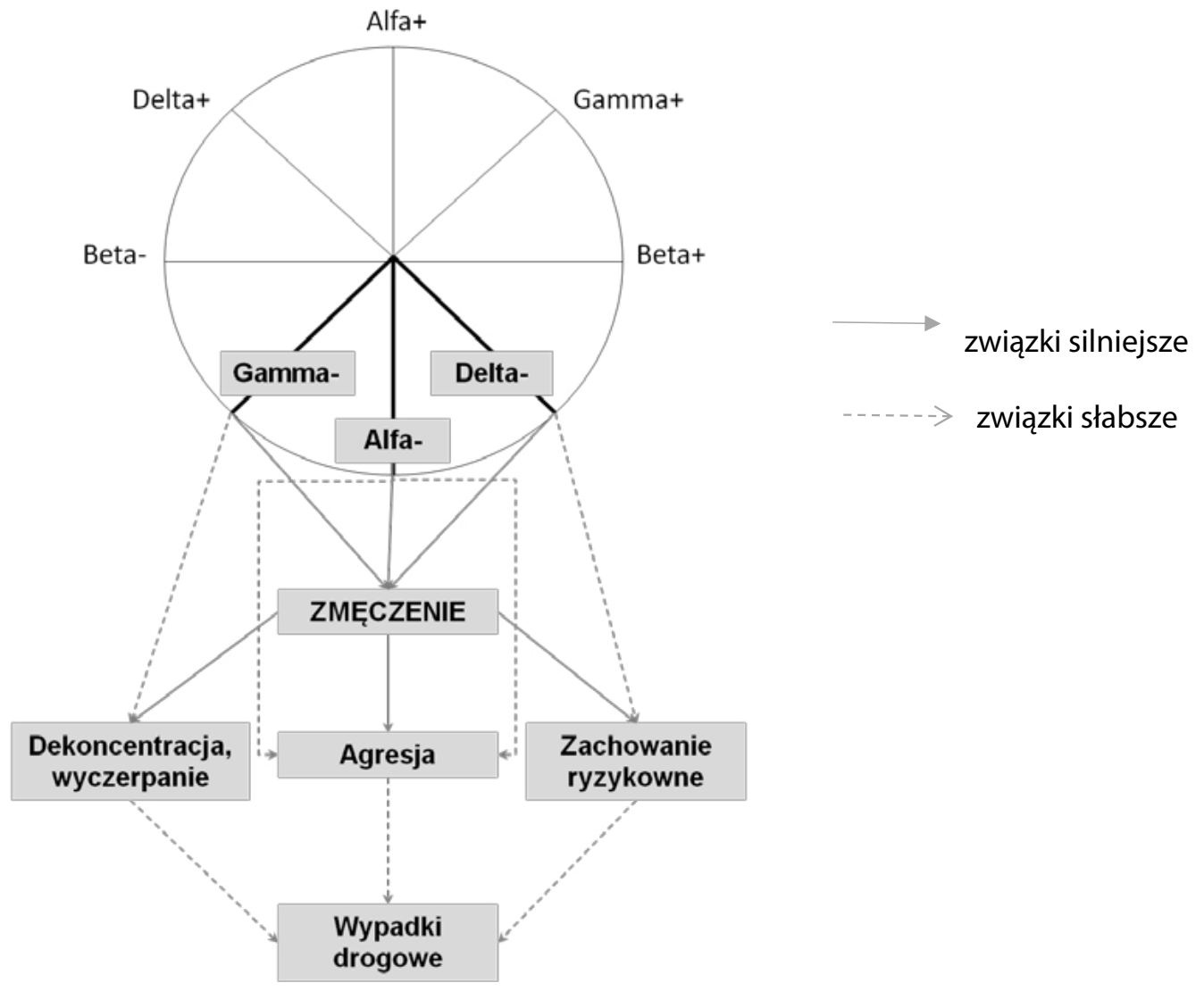

Rysunek 2. Schemat zakładanych związków między Kołowym Modelem Metacech Osobowości a podatnością na zmęczenie, skłonnością do zachowań ryzykownych i wypadkowością u kierowców.

Zatem wszystkie trzy metacechy: Delta-minus, Alfa-minus i Gamma-minus związane są z podatnością na zmęczenie (dzięki zawartej w nich wysokiej neurotyczności). Ale reakcje związane $\mathrm{z}$ ich wysokim poziomem są różne, jako że stan zmęczenia będzie uruchamiał obecne w nich tendencje emocjonalne i behawioralne, czyli poszukiwanie stymulacji przez zachowania ryzykowne u Delty-minus (dzięki konfiguracji S-, U-, E+, O+), agresywność u Alfy-minus (S-, U-) oraz dekoncentrację oraz wyczerpanie emocjonalne i motywacyjne u Gammy-minus (E-, S-, O-, U-). Z kolei każda z tych reakcji wiąże się ze wzrostem ryzyka spowodowania wypadku w ruchu drogowym. $Z$ drugiej strony, przeciwstawne do wspomnianych metacechy Delta-plus/Powściągliwość, Alfa-plus/Stabilność oraz Gamma-plus/Integracja można potraktować jako związane $z$ bezpiecznym stylem prowadzenia pojazdu oraz jako predyktory niskiego poziomu wykroczeń i wypadkowości w ruchu drogowym.

\section{ZAKOŃCZENIE}

Celem artykułu był przegląd wybranych badań nad osobowościowymi uwarunkowaniami ryzykownych zachowań, podatności na zmęczenie oraz wypadkowości (powodowania wypadków) w ruchu drogowym, a także prezentacja modelu KMMO jako propozycji integrującej i syntetyzującej dotychczasowe dane empiryczne. Sam model i jego możliwości integracji teoretycznej uzyskały już istotne wsparcie empiryczne (Strus, Cieciuch, 2017), 
zaprezentowane zaś wyżej powiązania opisywanych w nim metacech ze zmiennymi o istotnym znaczeniu z punktu widzenia ryzyka wypadków drogowych mają póki co status jedynie hipotez badawczych i wymagają bezpośredniej weryfikacji empirycznej. Przytoczone powyżej rezultaty badań można potraktować jako weryfikację pośrednią tych zależności, jednakże weryfikacja bezpośrednia ma dopiero nastąpić. Istotną informacją w tym kontekście jest fakt, że KMMO został już zoperacjonalizowany (Strus, Cieciuch, 2017), jest zatem możliwy bezpośredni pomiar metacech wyróżnionych w tym modelu.

Warto jednak także zwrócić uwagę, że schemat zaprezentowany na rysunku 2 i rola w nim KMMO stanowią propozycję wartościową badawczo, jest bowiem bardzo oszczędny (w sensie liczby postulowanych konstruktów) i konkretny, mamy tu do czynienia z zaledwie trzema osobowościowymi predyktorami trzech różnych form niebezpiecznych reakcji na drodze, ze zmęczeniem w roli mediatora. Ponadto schemat ten nie jest zbiorem pojedynczych hipotez, ale modelem, który można potraktować jako swoisty klucz interpretacyjny dla wyników dotychczasowych badań oraz „generator hipotez” dla badań przyszłych, przewiduje on bowiem co najmniej kilka interesujących zależności. Predykcje te mogą z kolei być weryfikowane w cyklu przynajmniej kilku badań o charakterze zarówno korelacyjnym (z analizami wielozmiennowymi), jak i quasi-eksperymentalnym. Wypada wyrazić nadzieję, że model zachęci badaczy do jego empirycznej weryfikacji, która mogłaby stanowić początek szerzej zakrojonych i praktycznie zorientowanych działań mających na celu poprawę bezpieczeństwa w ruchu drogowym.

\section{BIBLIOGRAFIA}

Ashton, M. C., Lee, K. (2007). Empirical, theoretical, and practical advantages of the HEXACO model of personality structure. Personality and Social Psychology Review, 11, 150-166. https://doi.org/10.1177/1088868306294907

Becker, P. (1999). Beyond the Big Five. Personality and Individual Differences, 26, 511-530. https://doi.org/10.1016/50191-8869(98)00168-8

Block, J. (1995). A contrarian view of the five-factor approach to personality description. Psychological Bulletin, 177, 187-215. https://doi. org/10.1037/0033-2909.117

Block, J. (2001). Millennial contrarianism: the five-factor approach to personality description 5 years later. Journal of Research in Personality, 35, 98-107. https://doi.org/10.1006/jpe.2000.2293

Burtăverde, V., Chraif, M., Ani ţei, M., Dumitru, D. (2017). The HEXACO model of personality and risky driving behavior. Psychological Reports, 120, 255-270. https://doi.org/10.1177/0033294116688890

Clarke, S., Robertson, I. T. (2005). A meta-analytic review of the Big Five personality factors and accident involvement in occupational and non-occupational settings. Journal of Occupational and Organizational Psychology, 78, 355-376. https://doi.org/10.1348/096317905X26183

Cloninger, C. R. (2004). Feeling good: the science of well-being. Nowy Jork: Oxford University Press.

Corr, P. J. (2009). The reinforcement sensitivity theory of personality. W: P. J. Corr, G. Matthews (red.), Cambridge Handbook of Personality (s. 347376). Cambridge: Cambridge University Press.

DeYoung, C. G. (2006). Higher-order factors of the Big Five in a multi-informant sample. Journal of Personality and Social Psychology, 91, 11381151. https://doi.org/10.1037/0022-3514.91.6.1138

DeYoung, C. G., Peterson, J. B., Higgins, D. M. (2002). Higher-order factors of the Big Five predict conformity: Are there neuroses of health? Personality and Individual Differences, 33, 533-552. https://doi.org/10.1016/S0191-8869(01)00171-4

DeYoung, C. G., Peterson, J. B., Seguin, J. R., Tremblay, R. E. (2008). Externalizing behavior and the higher-order factors of the Big Five. Journal of Abnormal Psychology, 117, 947-953. https://doi.org/10.1037/a0013742

Digman, J. M. (1997). Higher-order factors of the Big Five. Journal of Personality and Social Psychology, 73, 1246-1256. https://doi. org/10.1037/0022-3514.73.6.1246

Donnellan, M. B., Robins, R. W. (2010). Resilient, overcontrolled, and undercontrolled personality types: issues and controversies. Social and Personality Psychology Compass, 4, 1070-1083. https://doi.org/10.1111/j.1751-9004.2010.00313.x

Eysenck, H. J., Eysenck, M. W. (1985). Personality and individual differences: a natural science approach. Nowy Jork: Plenum Press.

Fukuda, S., Kuratsune, H., Tajima, S., Takashima, S., Yamagutchi, K., Nishizawa, Y., Watanabe, Y. (2010). Premorbid personality in chronic fatigue syndrome as determined by the Temperament and Character Inventory. Comprehensive Psychiatry, 51, 78-85. https://doi.org/10.1016/j. comppsych.2009.02.002

Gasiul, H. (2020). Psychologia osobowości: nurty - teorie - koncepcje (wyd. 3). Warszawa: Difin. 
Goldberg, L. R. (1999). A broad-bandwidth, public-domain, personality inventory measuring the lower-level facets of several Five-Factor models. W: I. Mervielde, I. Deary, F. De Fruyt, F. Ostendorf (red.), Personality Psychology in Europe (t. 7, s. 7-28). Tilburg: Tilburg University Press.

González, J. L., López-López, A., Alonso-Fernández, M., Ciudad, N., Matías-Pompa, B., Moreno-Jiménez, B. (2014). Fatigue as moderator of relationship between personality and the affective dimensions of well-being. Journal of Happiness Studies, 15, 1363-1376. https://doi. org/10.1007/s10902-013-9480-5

Gunthert, K. C., Cohen, L., Armelli, S. (1999). The role of neuroticism in daily stress and coping. Journal of Personality and Social Psychology, 77, 1087-1100. https://doi.org/10.1037/0022-3514.77.5.1087

Herzberg, Ph. Y. (2009). Beyond accident-proneness": using Five-Factor Model prototypes to predict driving behavior. Journal of Research in Personality, 43, 1096-1100. https://doi.org/10.1016/j.jp. 2009.08.008

Hirsh, J. B., DeYoung, C. G., Peterson, J. B. (2009). Metatraits of the Big Five differentially predict engagement and restraint of behavior. Journal of Personality, 77, 1085-1102. https://doi.org/10.1111/j.1467-6494.2009.00575.x

Just, C. (2011). A review of the literature on general factor of personality. Personality and Individual Differences, 50, 765-771. https://doi.org/10.1016/j. paid.2011.01.008

Kangas, M., Montgomery, G. H. (2011). The role of cognitive, emotional and personality factors in the experience of fatigue in university and community sample. Psychology and Health, 26, supl. 1, 1-19. https://doi.org/10.1080/08870440903521779

Matthews, G. (2011). Personality and individual differences in cognitive fatigue. W: P. L. Ackerman (red.), Cognitive fatigue: multidisciplinary perspectives on current research and future applications (s. 209-227). Waszyngton: APA. https://doi.org/10.1037/12343-010

Matthews, G., Campbell, S. E. (2009). Sustained performance under overload: personality and individual differences in stress and coping. Theoretical Issues in Ergonomics Science, 10, 417-442. https://doi.org/10.1080/14639220903106395

McAdams,D.P.(1992).Thefive-factormodelinpersonality:acritical appraisal.JournalofPersonality,60,329-361.https://doi.org/10.1111/j.1467-6494.1992. tb00976.x

McCrae, R. R., Costa, P. T., Jr. (2005). Osobowość dorosłego człowieka. Kraków: WAM.

McCrae, R. R., John, 0. P. (1992). An introduction to the five-factor model and its applications. Journal of Personality, 60, 175-215. https://doi. org/10.1111/j.1467-6494.1992.tb00970.x

Musek, J. (2007). A general factor of personality: evidence of the Big One in the five-factor model. Journal of Research in Personality, 41, 12131233. https://doi.org/10.1016/j.jp.2007.02.003

Revelle, W., Wilt, J. (2013). The general factor of personality: a general critique. Journal of Research in Personality, 47, 493-504. https://doi.org/10.1016/j. jrp.2013.04.012

Rogoza, R., Cieciuch, J., Strus, W., Baran, T. (2019). Seeking a common framework for research on narcissism: an attempt to integrate the different faces of narcissism within the Circumplex of Personality Metatraits. European Journal of Personality, 33, 437-455. http://doi.org/10.1002/ per.2206

Rushton, J. P., Irving, P. (2011). The General Factor of Personality: normal and abnormal. W: T. Chamorro-Premuzic, S. von Stumm, A. Furnham (red.), The Wiley-Blackwell handbook of individual differences (s. 132-161). Londyn: Blackwell.

Settles, R. E., Fischer, S., Cyders, M. A., Combs, J. L., Gunn, R. L., Smith, G. T. (2012). Negative urgency: a personality predictor of externalizing behavior characterized by neuroticism, low conscientiousness, and disagreeableness. Journal of Abnormal Psychology, 121, 160-172. https:// doi.org/10.1037/a0024948

Skimina, E., Strus, W., Cieciuch, J., Szarota, P., Izdebski, P. K. (2020). Psychometric properties of the Polish versions of the HEXACO-60 and the HEXAC0-100 personality inventories. Current /ssues in Personality Psychology, 8, 255-278. http://doi.org/10.5114/cipp.2020.98693

Strus, W. Cieciuch, J. (2014). Poza Wielką Piątkę - przegląd nowych modeli struktury osobowości. Polskie Forum Psychologiczne, 19, 17-49. https://doi.org/10.14656/PFP20140102

Strus, W., Cieciuch, J. (2017). Towards a synthesis of personality, temperament, motivation, emotion and mental health models within the Circumplex of Personality Metatraits. Journal of Research in Personality, 66, 70-95. https://doi.org/10.1016/j.jp. 2016.12.002

Strus, W., Cieciuch, J. (2021). The Circumplex of Personality Metatraits and the HEXACO model: toward refinement and integration. Journal of Personality. Advance online publication: https://doi.org/10.1111/JOPY.12616

Strus, W., Cieciuch, J., Rowiński, T. (2014a). The Circumplex of Personality Metatraits: a synthesizing model of personality based on the Big Five. Review of General Psychology, 18, 273-286. https://doi.org/10.1037/gpr0000017

Strus, W., Cieciuch, J., Rowiński, T. (2014b). The Polish adaptation of the IPIP-BFM-50 questionnaire for measuring five personality traits in the lexical approach. Annals of Psychology, 17, 347-366. Pobrane z: http://czasopisma.tnkul.pl/index.php/rpsych/article/view/3163

Strus, W., Cybis, N., Cieciuch, J., Rowiński, T. (2021). Number and content of personality types across methods and samples: empirical filling of the theoretically developed map of RUN0 typology. Polish Psychological Bulletin, 52(3), 211-226. https://doi.org/10.24425/ppb.2021.137886

Thayer, R. E. (1996). The origin of everyday moods: managing energy, tension, and stress. Nowy Jork: Oxford University Press.

Yamano, E., Fukuda, S., Joudoi, T., Mizuno, K., Tanaka, M., Kataoka, Y., ... Watanabe, Y. (2010). Temperament and character as predictors of fatigue-induced symptoms among school children in Japan: a 1-year follow-up study. Comprehensive Psychiatry, 51, 256-265. https://doi. org/10.1016/j.comppsych.2009.08.001

Zawadzki, B. (2017). The location of personality disorders in the Circumplex of Personality Metatraits. Annals of Psychology, 20, 493-512. https:// doi.org/10.18290/rpsych.2017.20.2-7en 
Zawadzki, B., Strelau, J. (2003). Identyfikacja trzech podstawowych prototypów osobowości w grupach polskich: próba reorientacji badań nad osobowością z koncepcji cech w koncepcję typów. Studia Psychologiczne, 41(4), 217-242.

Zawadzki, B., Strelau, J. (2014). 0 (nie)trafności ogólnego czynnika osobowości. Roczniki Psychologiczne, 17, 259-274. 